\title{
THE EFFECT OF DIFFERENT IRRIGATION LEVELS AND MULCH APPLICATION ON SOME QUALITY CRITERIA IN TABLE TOMATOES (LYCOPERSICON ESCULENTUM MILL.)
}

\author{
KARAER, M. ${ }^{1 *}-$ Kuscu, H. ${ }^{2}-$ Gultas, H. T. ${ }^{1}$ \\ ${ }^{I}$ Department of Biosystems Engineering, Faculty of Agriculture and Natural Sciences, Bilecik \\ Şeyh Edebali University, Bilecik, Turkey \\ ${ }^{2}$ Department of Biosystems Engineering, Faculty of Agriculture, Bursa Uludag University, \\ Bursa, Turkey \\ *Corresponding author \\ e-mail: murat.karaer@bilecik.edu.tr; phone: +90-228-214-1797
}

(Received $2^{\text {nd }}$ Mar 2020; accepted $3^{\text {rd }}$ Jul 2020)

\begin{abstract}
The aim of the study was to measure the response of tomato (Lycopersicon esculentum Mill.) grown in open field to mulch and different irrigation levels. This study was carried out in Bilecik, Turkey in the growing season of 2017 and 2018. The research was designed as a split plot design with 3 replications. The treatments consist of two mulch [black nylon mulch (M) and no mulch (NM)] and four irrigation levels of pan evaporation (Epan) replenishment $\left[1.00 \times\right.$ Epan $\left(I_{100}\right), 0.75 \times$ Epan $\left(I_{75}\right), 0.50 \times$ Epan $\left(\mathrm{I}_{50}\right), 0.25 \times$ Epan $\left.\left(\mathrm{I}_{25}\right)\right]$. As a result of the research, irrigation water level and mulch application was found to have significant effects on some quality criteria. The study shows that $\mathrm{pH}$, fruit puncture resistance, fruit diameter, fruit length and total soluble solids/titration acidity ratio increased with increasing amount of irrigation water. As irrigation water level in mulch application increased, fruit diameter, weight, $\mathrm{pH}$ and fruit puncture resistance values increased. Mulch application yielded better results than application without mulch irrespective of irrigation levels.
\end{abstract}

Keywords: colour, fruit puncture, semi-arid climate, titration acidity, total soluble solids

\section{Introduction}

The rapid increase in population is expected to bring food shortages along with water shortages. The problem is the imbalance between the global increase in food demand and the reduction in available water resources. Therefore, existing water resources should be well protected and used rationally.

When we look at the sectoral use of the existing water resources in the world, agricultural use ranks first with $70 \%$, industry with $19 \%$ and domestic use with $11 \%$ approximately (FAO, 2013; Anonymous, 2014). These rates show that the rational use of water resources in agricultural sector, which is the largest user of water becomes more important. However, increasing water demand for domestic use and industry, irregularity in the precipitation regime due to global climate change, pollution of usable water resources and/or the desiccation of some of these sources will make it necessary to limit the amount of water to be allocated to agriculture in the near future. While the amount of irrigated land all over the world was 170 million ha in the 1970 s, this ratio reached 304 million ha in 2008 and by 2025 it is estimated to reach 330 million ha (FAO, 2011). However, it is predicted that the population of the world will be 8 billion by 2025 . In order to meet the needs of the population by 2025 , the amount of irrigated land should be higher than $20 \%$ of the total amount of agricultural land and the crop yield obtained from irrigated land should be $40 \%$ higher than that currently obtained 
(Lascano and Sojka, 2007). This makes it necessary to use the soil and water potential allocated for agricultural purposes with the highest possible efficiency and to obtain the highest yield from a unit of water used. Therefore, the approach in irrigated agriculture has been focusing on obtaining more products with less water. Deficit irrigation and partial root drying (PRD) techniques are water-saving methods that reduce the amount of water supplied to plants compared to full irrigation (Ahmadi et al., 2010).

The aim of deficit irrigation is to increase the efficiency of plant water use by reducing the amount or frequency of irrigation water. The plant which is made deficit irrigation is exposed to water stress at any period of development or during the growing season and it is expected to save water without causing a significant decrease in yield. Deficit irrigation can also be used to create new irrigation areas where water resources are sufficient. The plant type to be chosen is also important in deficit irrigation. Plant's response to deficit irrigation and the water-saving should be at the forefront. Tomato is a plant which requires much water is the most grown vegetable in the world and in Turkey. In this respect, it is a suitable plant in terms of the reactions to be achieved by shortened irrigation.

Tomato (Solanum lycopersicum L.) is a single-year vegetable species of the eggplant family (Solanoceae), native to South and Central America, widely used in human nutrition. Approximately 1.1 billion tons of fresh vegetables are produced in the world annually and about 177 million tons of this are tomatoes. This makes tomato to be ranked as the most grown vegetable among other vegetables and it covers the largest area with 4.8 million ha. With 176.000 ha area, Turkey has the 4 th biggest area of tomato production after China, India and Egypt. In addition to this, with 12.2 million tons of production, Turkey is the 4 th biggest producer of tomato after China, India and America (FAO, 2018).

Many irrigation studies have shown that tomato is sensitive to water stress (Locascio and Smasjstrla, 1996; Patanè and Cosentino, 2010). Water and nutrient stress leads to reduction in marketable yields and quality. In order to obtain high yields, seasonal water requirement of tomatoes range from 400 to $800 \mathrm{~mm}$ with a daily evapotranspiration rate of 4 to $6 \mathrm{~mm}$ (Salokhe et al., 2005; Hanson and May, 2006; Mukherjee et al., 2010).

Irrigation water level and scheduling of irrigation application significantly affect tomato yield and fruit quality (Wang et al., 2012). Previous studies show that deficit irrigation can increase water use efficiency (WUE) and improve tomato quality in the tomato plant (Zegbe-Dominguez et al., 2003; Favati et al., 2009; Kuşçu et al., 2014). On the other hand, deficit irrigation practices can result the fruits to be small in size, lower marketable yields and higher susceptibility to various diseases (Favati et al., 2009).

The use of mulch has many benefits in agriculture as it reduces weed output which causes yield losses and diseases. Moreover, it provides better root growth by increasing soil temperature. It reduces surface evaporation and maintains soil moisture, thus saves water. Furthermore, the use of mulch has a significant impact on earliness, productivity and fruit quality (Abak et al., 1990; Koçar, 2001; Ünlü et al., 2006; Ekinci and Dursun, 2009; Kurtar, 2010; Korkmaz and Balkaya, 2016). However, the number of studies on the effect of both different irrigation regimes and mulch applications on the quality characteristics of table tomatoes is quite limited. In addition, the response of plants to cultural practices in different varieties, climatic and soil characteristics may also change. Therefore, this study was conducted to determine the effects of different irrigation levels and mulch application on the quality of table tomatoes in Bilecik, a semi-arid climate zone. 


\section{Materials and methods}

The research was carried out in the open field, in the growing season of 2017 and 2018, in the Research and Application Area of Bilecik Şeyh Edebali University, Faculty of Agriculture and Natural Sciences. The experiment area is located at $40^{\circ} 6^{\prime} \mathrm{N}, 30^{\circ} .0^{\prime}$ $\mathrm{E}$; altitude $500 \mathrm{~m}$ above the sea level. Both the climate of Marmara Region and Central Anatolia Region are influential in Bilecik province. According to the long-term meteorological data, the average annual rainfall in the region is $450 \mathrm{~mm}$ and the average temperature is $12.5^{\circ} \mathrm{C}$. According to annual rainfall, the study area is defined as semiarid. Climate data for the years of study are given in Tables 1 and 2 .

Table 1. Climate data for 2017

\begin{tabular}{c|c|c|c|c|c|c|c|c|c|c|c|c|c}
\hline & Jan & Feb & Mar & Apr & May & Jun & Jul & Aug & Sep & Oct & Nov & Dec & Yearly \\
\hline Average temperature $\left({ }^{\circ} \mathrm{C}\right)$ & 0.4 & 5.7 & 9.3 & 11.7 & 16 & 21 & 23.8 & 23.1 & 21.4 & 13.2 & 9 & 6.6 & 13.5 \\
\hline Average Highest Temperature $\left({ }^{\circ} \mathrm{C}\right)$ & 3.7 & 9.8 & 15 & 18.6 & 22.5 & 27.1 & 31.2 & 29.9 & 29.5 & 19 & 13.7 & 9.9 & 19.2 \\
\hline Average Lowest Temperature $\left({ }^{\circ} \mathrm{C}\right)$ & -2.2 & 1.5 & 5.2 & 6.4 & 11.4 & 15.3 & 17.8 & 18.4 & 15.4 & 8.9 & 5.7 & 4.3 & 9 \\
\hline $\begin{array}{c}\text { Average of Total Monthly Rainfall } \\
(\mathrm{mm})\end{array}$ & 51.0 & 9.3 & 26 & 64.4 & 56.7 & 69.9 & 7.0 & 16 & 3.0 & 44.4 & 21.1 & 66.2 & 435 \\
\hline
\end{tabular}

Table 2. Climate data for 2018

\begin{tabular}{c|c|c|c|c|c|c|c|c|c|c|c|c|c}
\hline & Jan & Feb & Mar & Apr & May & Jun & Jul & Aug & Sep & Oct & Nov & Dec & Yearly \\
\hline Average temperature $\left({ }^{\circ} \mathrm{C}\right)$ & 4 & 7.3 & 12.9 & 16 & 18.2 & 21.2 & 23.8 & 24.1 & 19.5 & 14.7 & 9.6 & 3.5 & 14.6 \\
\hline Average Highest Temperature $\left({ }^{\circ} \mathrm{C}\right)$ & 7.2 & 11.7 & 16.5 & 23.3 & 24.2 & 28.1 & 30 & 31.2 & 26.1 & 19.9 & 13.7 & 5.8 & 19.8 \\
\hline Average Lowest Temperature $\left({ }^{\circ} \mathrm{C}\right)$ & 1.4 & 4.5 & 7 & 9.8 & 14 & 15.7 & 18.4 & 18.7 & 14.7 & 11.3 & 6.8 & 5.8 & 10.7 \\
\hline $\begin{array}{c}\text { Average of Total Monthly Rainfall } \\
(\mathrm{mm})\end{array}$ & 40.9 & 37.6 & 66.1 & 18.6 & 80.8 & 39.5 & 14.2 & 17.8 & 89.4 & 46.4 & 37 & 107.3 & 595.6 \\
\hline
\end{tabular}

The study area has a clay loam soil structure (38.66\% sand, $32.81 \%$ clay and $28.53 \%$ loam). The physical analysis results of the soil of the trial area are given in Table 3. Total rainfall during the plant growing season was $94.7 \mathrm{~mm}$ in 2017 and $116.3 \mathrm{~mm}$ in 2018.

Table 3. The physical analysis results of soil samples

\begin{tabular}{c|c|c|c|c|c|c}
\hline \multirow{2}{*}{$\begin{array}{c}\text { Depth } \\
(\mathbf{c m})\end{array}$} & \multicolumn{3}{|c|}{ Grain size } & \multirow{2}{*}{ Texture } & $\begin{array}{c}\text { Volume weight } \\
\left(\mathbf{g} / \mathbf{c m}^{\mathbf{3}}\right)\end{array}$ & $\begin{array}{c}\text { Field capacity } \\
(\mathbf{P W} \%)\end{array}$ \\
\cline { 2 - 4 } & Sand & Silts & Clay & & 1.26 & 27.87 \\
$0-30$ & 38.66 & 32.81 & 28.53 & CL & 1.21 & 24.57 \\
$30-60$ & 42.05 & 32.11 & 25.84 & L & 1.27 & 26.67 \\
$60-90$ & 39.71 & 34.34 & 25.95 & L & \\
\hline
\end{tabular}

The working area was first plowed and the land surface was leveled and suitable conditions for planting were prepared. Weed control was done by hand and hoeing three times until the first harvest. Nitrogen, phosphorus and potash fertilizers were used in fertilization. Fertilization was given to plants by drip irrigation system after planting. 
In the study, Zahide F1 tomato variety was used. It is suitable for spring and summer planting. Its fruits are flat and round. It is an early variety and the average harvest time is 70-90 days.

Treatments were arranged in the field according to a split-plot experimental design with three replications in both seasons. The mulch treatments were randomized in the main plots and irrigation levels in the sub-plots. The treatments consist of two mulch [black nylon mulch (M) and no mulch (NM)] and four irrigation levels of pan evaporation (Epan) replenishment [1.00×Epan $\left(\mathrm{I}_{100}\right), 0.75 \times$ Epan $\left(\mathrm{I}_{75}\right), 0.50 \times$ Epan $\left(\mathrm{I}_{50}\right), 0.25 \times$ Epan $\left.\left(\mathrm{I}_{25}\right)\right]$. The irrigations were carried out at 5-day intervals according to the drip irrigation method. Each experimental plot was $6 \mathrm{~m}$ long and $3.2 \mathrm{~m}$ wide $\left(19.2 \mathrm{~m}^{2}\right)$, with 4 rows. Plots are placed leaving two meters buffer zones between. The row spacing was $0.8 \mathrm{~m}$ and plan-plant spacing was $0.4 \mathrm{~m}$.

The irrigations were carried out according to five-days evaporation amount cumulated in Class A pan. The amount of irrigation water was determined by multiplying the measured evaporation value with the kp coefficient, wetting percentage, kc coefficient, and area (Eq. 1; Kanber, 1984).

$$
\mathrm{I}=\mathrm{A} \times \mathrm{Ep} \times \mathrm{kp} \times \mathrm{P} \times \mathrm{kc}
$$

In Equation 1, I is irrigation water applied to the parcel (litres), $A$ is parcel area $\left(\mathrm{m}^{2}\right), E p$ is accumulated evaporation amount from open water surface $(\mathrm{mm}), k p$ is coefficient for experiment treatments, $P$ is wetting percentage, and $k c$ is coefficient at different growth periods.

The $k c$ coefficient was taken 0.60 in the initial period, between $0.60-1.15$ in the development period, 1.15 in the medium period, and 1.15-0.80 in the last period (Allen et al., 1998). Table 4 shows that coefficients for experimental treatments.

Table 4. Coefficients for irrigation treatments

\begin{tabular}{c|c}
\hline Irrigation treatment & kp coefficient \\
\hline $\mathrm{I}_{100}$ & 1.00 \\
$\mathrm{I}_{75}$ & 0.75 \\
$\mathrm{I}_{50}$ & 0.50 \\
$\mathrm{I}_{25}$ & 0.25 \\
\hline
\end{tabular}

Throughout the growing season, the measurement of the crop-water requirement is made based on 0-90 cm depth increment of the soil as in Equation 2 (Garrity et al., 1982).

$$
\mathrm{ET}=\mathrm{I}+\mathrm{P} \pm \Delta \mathrm{S}-\mathrm{D}
$$

In Equation 2, ET is plant water consumption $(\mathrm{mm}), I$ is irrigation water $(\mathrm{mm}), P$ is precipitation amount $(\mathrm{mm}), D$ is deep drainage losses $(\mathrm{mm})$, and $\Delta S$ is refers to the moisture change $(\mathrm{mm})$ in the soil profile.

For the harvest, the edge rows of each parcel were discarded and the two rows in the middle were determined as the harvest area. Harvestes continued until mid-October.

Quality characteristics of fruit were determined by examining 20 fruit samples randomly selected from each parcel. In order to determine the quality characteristics, the 
diameter, length, $\mathrm{pH}$ ratio, perforation resistance and total soluble solids (TSS) and titration acidity (TA) of the fruit were examined.

The average fruit width was determined by measuring the widest diameter of the fruit with a digital calliper. The average fruit length was determined by measuring the distance between the stem pit and floral nose with a digital calliper. In order to determine the $\mathrm{pH}$ ratio, fruit juices were obtained through a blender after the tomatoes were harvested and measurements were carried out by $\mathrm{pH}$ meter (Cemeroğlu, 2010). Fruit perforation resistance was measured by flat-tipped hand penetrometer at 3 different locations in the equator region of the fruit and the results were expressed as $\mathrm{kg}$ $\mathrm{cm}^{-2}$. Tomato juice was titrated with $0.1 \mathrm{~N} \mathrm{NaOH}$ until the $\mathrm{pH}$ of the tomato juice reached up to 8.1. The amount of acid consumed was calculated in terms of citric acid (mg/100 g citric acid) and titration acidity was found. The fruit juice obtained by blending the tomatoes was filtered in order to determine total soluble solids. Then, the sample taken from the filtered fruit juice was dropped onto the hand refractometer and the results were read and determined as \% (Cemeroğlu, 2010). TSS/TA value was obtained by dividing the obtained TSS and TA values. In determining the colours of tomato samples, $\mathrm{a}$ and $\mathrm{b}$ values were measured by colour measurement device. Minitab18 package program was used for statistical evaluation of the obtained results.

\section{Results and discussion}

Results of variance analysis (ANOVA) of the data are given in Table 5. The results show that the effect of irrigation regimes on all measured parameters was significant at $P<0.01$ level. Mulch application was significant at $\mathrm{P}<0.01$ level for fruit diameter, length, and colour parameters. On addition, the effect of interactions between irrigation and mulch was significant at $\mathrm{P}<0.01$ level, on all parameters.

Table 5. Result of variance of fruit diameter, length, $p H$ ratio, perforation resistance and TSS/TA ratio for the irrigation and mulch treatments

\begin{tabular}{c|c|c|c|c|c|c|c}
\hline Variables & pH & $\begin{array}{c}\text { Fruit perforation } \\
\text { resistance }\end{array}$ & $\begin{array}{c}\text { Fruit } \\
\text { diameter }\end{array}$ & $\begin{array}{c}\text { Fruit } \\
\text { length }\end{array}$ & Colour a & Colour b & $\begin{array}{c}\text { TSS/TA } \\
\text { ratio }\end{array}$ \\
\hline Year (Y) & $\mathrm{ns}$ & $\mathrm{ns}$ & $* *$ & $* *$ & $\mathrm{~ns}$ & $\mathrm{~ns}$ & $* *$ \\
Irrigation level (I) & $* *$ & $* *$ & $* *$ & $* *$ & $* *$ & $* *$ & $* *$ \\
Mulch application (MA) & $\mathrm{ns}$ & $\mathrm{ns}$ & $* *$ & $* *$ & $* *$ & $* *$ & $\mathrm{~ns}$ \\
I $\times$ MA & $* *$ & $* *$ & $* *$ & $* *$ & $* *$ & $* *$ & $* *$ \\
$\mathrm{Y} \times \mathrm{I} \times \mathrm{MA}$ & $* *$ & $* *$ & $* *$ & $* *$ & $* *$ & $* *$ & $\mathrm{~ns}$ \\
\hline
\end{tabular}

$*$, **, and ns: F-test significant at $\mathrm{p} \leq 0.005, \mathrm{p} \leq 0.01$, respectively, and not significant

\section{Irrigation water applied and evapotranspiration}

In this study, $15 \mathrm{~mm}$ water was given to the all test plots immediately after planting. Then, $30 \mathrm{~mm}$ of irrigation water in total was given to the plants in two times until the beginning of all subjects' irrigation application. In this study, irrigation was launched on the $18^{\text {th }}$ of June for both years. In 2017, 19 irrigations, and in 2018, 18 irrigations were performed. Irrigations were performed in 5 days intervals after planting. The amount of irrigation water applied to the experiment subjects and the crop water consumption amounts of the subjects are given in Table 6 and the cumulative amount of irrigation water is shown in Figures 1 and 2. 


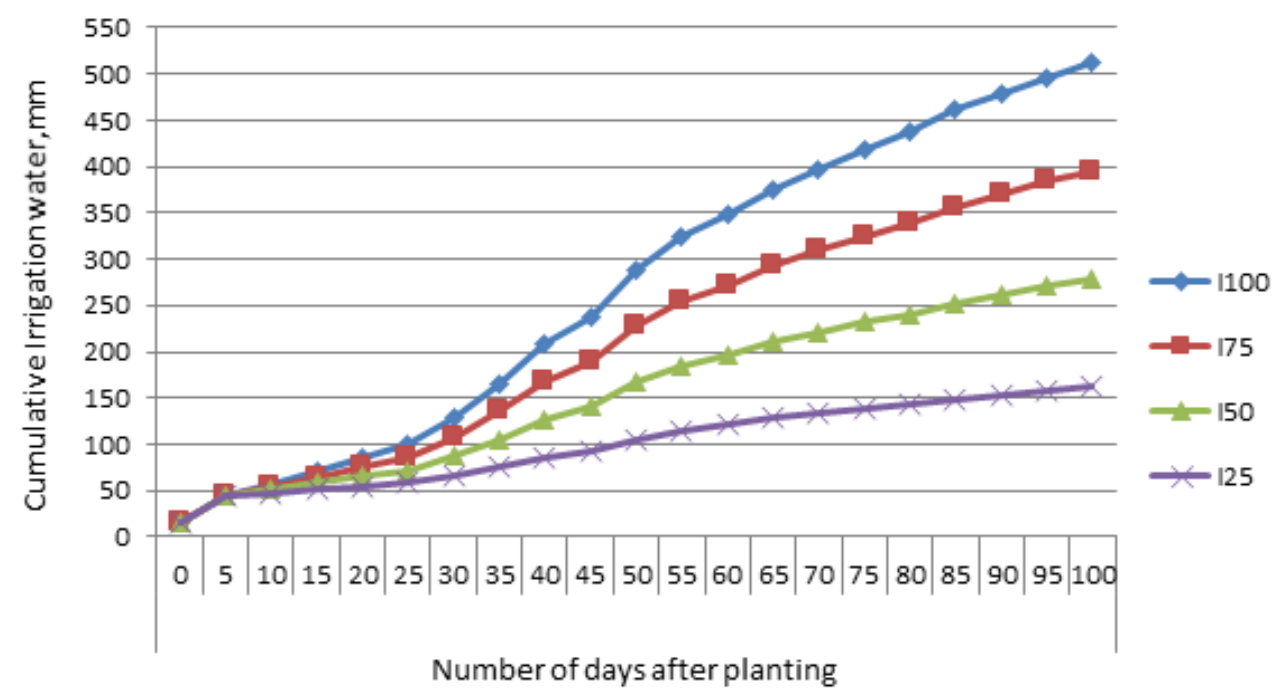

Figure 1. The amount of cumulative irrigation water in 2017

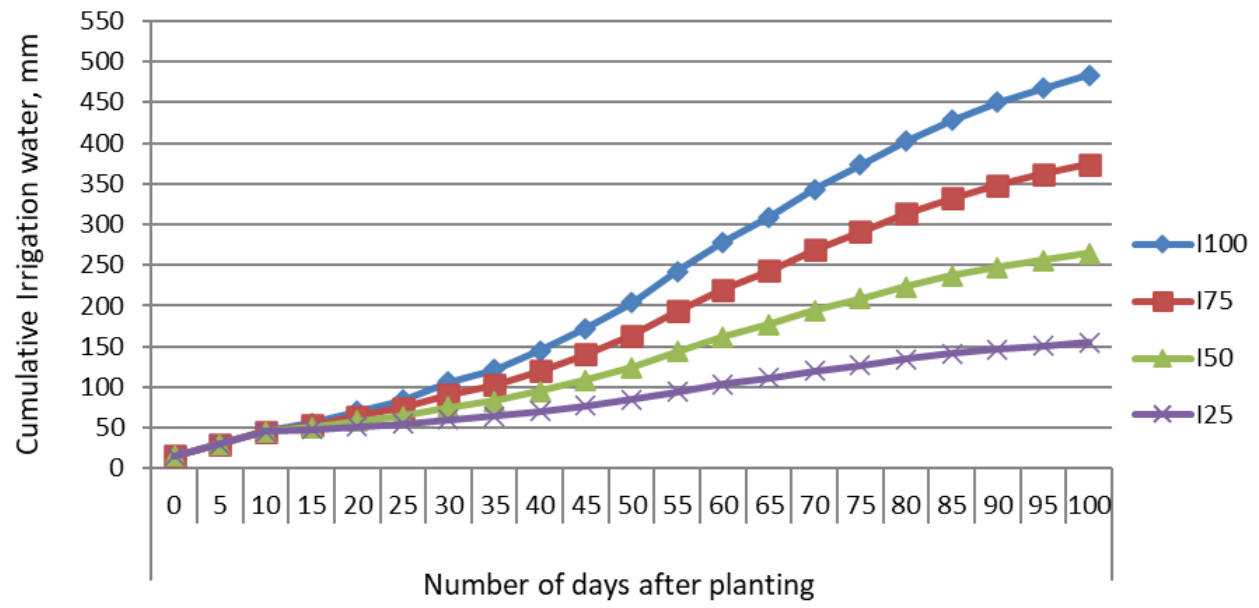

Figure 2. The amount of cumulative irrigation water in 2018

Table 6. Irrigation water applied (IWA) and seasonal evapotranspiration (ET)

\begin{tabular}{c|c|c|c|c}
\hline \multirow{2}{*}{ Applications } & \multicolumn{2}{|c|}{ IWA (mm) } & \multicolumn{2}{c}{ ET (mm) } \\
\cline { 2 - 5 } & $\mathbf{2 0 1 7}$ & $\mathbf{2 0 1 8}$ & $\mathbf{2 0 1 7}$ & $\mathbf{2 0 1 8}$ \\
\hline $\mathrm{I}_{25} \mathrm{M}$ & 161 & 154 & 266 & 276 \\
$\mathrm{I}_{25} \mathrm{NM}$ & 161 & 154 & 247 & 268 \\
$\mathrm{I}_{50} \mathrm{M}$ & 278 & 264 & 374 & 358 \\
$\mathrm{I}_{50} \mathrm{NM}$ & 278 & 264 & 326 & 350 \\
$\mathrm{I}_{75} \mathrm{M}$ & 395 & 373 & 450 & 474 \\
$\mathrm{I}_{75} \mathrm{NM}$ & 395 & 373 & 488 & 510 \\
$\mathrm{I}_{100} \mathrm{M}$ & 512 & 483 & 558 & 579 \\
$\mathrm{I}_{100} \mathrm{NM}$ & 512 & 483 & 570 & 593 \\
\hline
\end{tabular}


Irrigation continued at intervals of 5 days in 100 days after the planting as shown in Figures 1 and 2. Irrigation water and evapotranspiration values changed according to the experimental treatments. In 2017, irrigation water ranged from 161 to $512 \mathrm{~mm}$ and evapotranspiration ranged from 266 to $570 \mathrm{~mm}$. In 2018, irrigation water ranged between 154-483 $\mathrm{mm}$ and evapotranspiration ranged from $276-593 \mathrm{~mm}$. The highest evapotranspiration was obtained from $\mathrm{I}_{100} \times \mathrm{NM}$ and the lowest water consumption was obtained from $\mathrm{I}_{25} \times \mathrm{NM}$ in both years. Mukherjee et al. (2010) obtained the highest water consumption from the subject without mulch where irrigation started, when the cumulative pan evaporation was $25 \mathrm{~mm}$. Similarly, Hatami et al. (2012) obtained the highest water consumption from the subject without mulch.

\section{Quality characteristics}

$\mathrm{pH}$ is a criterion taken into consideration in the evaluation of tomato quality. The differences in the fruit $\mathrm{pH}$ among irrigation regimes were significant both for 2017 and 2018. The $\mathrm{pH}$ decreased as the irrigation rate was decreased. The highest $\mathrm{pH}$ values, 4.60 and 4.57 were obtained in the $\mathrm{I}_{100} \times \mathrm{M}$ and $\mathrm{I}_{100} \times \mathrm{NM}$ combination in 2017 respectively. On the other hand, the highest $\mathrm{pH}$ value, 4.62 was obtained in the $\mathrm{I}_{100} \times \mathrm{M}$ combination in 2018. Similar results were obtained in some studies on this subject and it was observed that the $\mathrm{pH}$ content decreased as irrigation water amount decreased (Ünlü et al., 2006; Lahoz et al., 2016; Tar1 and Sapmaz, 2017).

The perforation resistance of fruits in table tomatoes is an important quality criterion and is significantly affected by agricultural processes applied in cultivation. The results of the presents study shows that perforation resistance of the fruits decreases as the irrigation rate decreases. The highest perforation resistance values, 1.618 and $1.613 \mathrm{bar}$ were obtained in the $\mathrm{I}_{100} \times \mathrm{M}$ and $\mathrm{I}_{100} \times \mathrm{NM}$ combination in 2017 , respectively. The highest perforation resistance value, 1.64 was obtained in the $\mathrm{I}_{100} \times \mathrm{M}$ and $\mathrm{I}_{100} \times \mathrm{NM}$ in 2018. Lahoz et al. (2016), Ünlü et al. (2006) and Tarı and Sapmaz (2017), have reached similar results in their studies.

The highest fruit diameter was obtained in full irrigation $\left(\mathrm{I}_{100}\right)$ application in both years. Mulch application was found to be statistically significant and fruit diameter was found to be higher in mulch applications. Fruit diameter values ranged between 44.62$62.02 \mathrm{~mm}$ in 2017 and ranged between $51.73-66.40 \mathrm{~mm}$ in 2018. The highest values were obtained in $\mathrm{I}_{100} \times \mathrm{M}$ application from $62.02 \mathrm{~mm}$ to $66.40 \mathrm{~mm}$ respectively in both years. The lowest values were obtained in $\mathrm{I}_{25} \times \mathrm{NM}$ application from 44.62 to $51.73 \mathrm{~mm}$ respectively in both years. Fruit diameter was observed to increase as irrigation water increased. The same situation was also observed in mulch application. Özbahçe and Tarı (2009), Ertek et al. (2012) have reached similar results in their studies and reported fruit diameter was increase as irrigation water increased. Biswas et al. (2015) and Samaila et al. (2011) reported that fruit diameter was increased with mulch application

The highest fruit length was obtained in full irrigation $\left(\mathrm{I}_{100}\right)$ application in both years. Mulch application was found to be statistically significant and fruit length was found to be higher in mulch applications. Fruit length values ranged between $34.00-46.79 \mathrm{~mm}$ in 2017 and it ranged between 42.50-48.06 mm in 2018. In 2017, the highest fruit length was obtained from $\mathrm{I}_{100} \times \mathrm{M}, \mathrm{I}_{100} \times \mathrm{NM}$ and $\mathrm{I}_{75} \times \mathrm{NM}$ interactions as $46.99 \mathrm{~mm}$, $46.71 \mathrm{~mm}$ and $46.57 \mathrm{~mm}$ respectively. In 2018, it was obtained from $\mathrm{I} 100 \times \mathrm{M}$ interaction as $48.06 \mathrm{~mm}$. The results show that the fruit size increased as the irrigation level increased. The same is valid for the mulch application. Ertek et al. (2012) and Biswas et al. (2015), have reached similar results in their studies. 
The TSS/TA ratio has a better effect on the acid on fruit taste than soluble solids or titratable acidity. This is because the acid content tends to decrease with the ripening of the fruit while the sugar content tends to increase (Zoran et al., 2014). In the present study, mulch was not found to be statistically significant, but it was observed that irrigation level affected the TSS/TA ratio statistically. In 2017, the highest TSS/TA values were obtained from $\mathrm{I}_{100} \times \mathrm{M}, \mathrm{I}_{75} \times \mathrm{M}$ and $\mathrm{I}_{75} \times \mathrm{NM}$ interactions as 23.12, 22.62, and 22.61 respectively. In 2018, the highest value was obtained from $\mathrm{I}_{75} \times \mathrm{NM}$ as 26.84 . Irrigation level was found to be significant in both years and $\mathrm{I}_{75}$ irrigation gave the best results statistically.

Colour $b$ value of the fruit is a quality criterion that expresses the yellowness of the fruit surface. Mulch and irrigation level were found to be statistically significant for the colour value of the fruit. It was observed that the $b$ value gets higher when the irrigation level decreases. In 2018, the highest b values were obtained from the interactions of $\mathrm{I}_{25}$ $\times \mathrm{NM}, \mathrm{I}_{75} \times \mathrm{M}, \mathrm{I}_{50} \times \mathrm{NM}$ and $\mathrm{I}_{25} \times \mathrm{M}$, respectively, as 30.36, 29.76, 29.61, and 29.58. In conclusion, mulch, irrigation and mulch $\times$ irrigation interaction were found to be statistically significant.

Colour a value of the fruit is a quality criterion that expresses the redness of the fruit surface. Mulch and irrigation level were found to be statistically significant for colour a value in the fruit. The a value of the fruit varied between 32.89 and 34.45 in mulch application and between 32.16 and 37.39 in no mulch application. The highest a value was obtained from $\mathrm{I}_{100} \times \mathrm{NM}$ and $\mathrm{I}_{25} \times \mathrm{NM}$ interactions, as 37.39 and 36.58, respectively. In conclusion, mulch, irrigation and mulch $\times$ irrigation interaction were found to be statistically significant (Table 7).

Table 7. Irrigation $\times$ mulch application interactions for the fruit quality parameters

\begin{tabular}{|c|c|c|c|c|c|}
\hline \multicolumn{3}{|c|}{ pH } & \multicolumn{3}{|c|}{ Fruit perforation resistance } \\
\hline Irrigation & Mulch & No mulch & Irrigation & Mulch & No mulch \\
\hline \multicolumn{3}{|c|}{2017 yr } & \multicolumn{3}{|c|}{2017 yr } \\
\hline $\mathrm{I}_{25}$ & $4.343 \mathrm{c}$ & $4.320 \mathrm{c}$ & $\mathrm{I}_{25}$ & $1.266 \mathrm{c}$ & $1.240 \mathrm{c}$ \\
\hline $\mathrm{I}_{50}$ & $4.433 \mathrm{bc}$ & $4.426 \mathrm{bc}$ & $\mathrm{I}_{50}$ & $1.386 \mathrm{abc}$ & $1.333 \mathrm{bc}$ \\
\hline $\mathrm{I}_{75}$ & $4.500 \mathrm{ab}$ & $4.496 \mathrm{ab}$ & $\mathrm{I}_{75}$ & $1.486 \mathrm{abc}$ & $1.586 \mathrm{ab}$ \\
\hline $\mathrm{I}_{100}$ & $4.603 \mathrm{a}$ & $4.570 \mathrm{a}$ & $\mathrm{I}_{100}$ & $1.618 \mathrm{a}$ & $1.613 \mathrm{a}$ \\
\hline \multicolumn{3}{|c|}{$2018 \mathrm{yr}$} & \multicolumn{3}{|c|}{2018 yr } \\
\hline $\mathrm{I}_{25}$ & $4.360 \mathrm{~d}$ & $4.326 \mathrm{~d}$ & $\mathrm{I}_{25}$ & $1.286 \mathrm{~cd}$ & $1.206 \mathrm{~d}$ \\
\hline $\mathrm{I}_{50}$ & $4.423 \mathrm{~cd}$ & $4.426 \mathrm{~cd}$ & $\mathrm{I}_{50}$ & $1320 \mathrm{bcd}$ & $1.286 \mathrm{~d}$ \\
\hline $\mathrm{I}_{75}$ & $4.506 \mathrm{bc}$ & $4.503 \mathrm{bc}$ & $\mathrm{I}_{75}$ & $1.480 \mathrm{abc}$ & $1.513 \mathrm{ab}$ \\
\hline $\mathrm{I}_{100}$ & $4.623 \mathrm{a}$ & $4.583 \mathrm{ab}$ & $\mathrm{I}_{100}$ & $1.640 \mathrm{a}$ & $1.640 \mathrm{a}$ \\
\hline \multicolumn{3}{|c|}{ Fruit diameter } & \multicolumn{3}{|c|}{ Fruit length } \\
\hline Irrigation & Mulch & No mulch & Irrigation & Mulch & No mulch \\
\hline \multicolumn{3}{|c|}{$2017 \mathrm{yr}$} & \multicolumn{3}{|c|}{$2017 \mathrm{yr}$} \\
\hline $\mathrm{I}_{25}$ & $47.49 \mathrm{~cd}$ & $44.62 \mathrm{~d}$ & $\mathrm{I}_{25}$ & $35.52 \mathrm{c}$ & $34.00 \mathrm{c}$ \\
\hline $\mathrm{I}_{50}$ & $54.09 \mathrm{~b}$ & $46.87 \mathrm{~cd}$ & $\mathrm{I}_{50}$ & $42.51 \mathrm{~b}$ & $35.55 \mathrm{c}$ \\
\hline $\mathrm{I}_{75}$ & $58.83 \mathrm{ab}$ & $53.09 \mathrm{bc}$ & $\mathrm{I}_{75}$ & $44.14 \mathrm{~b}$ & $46.71 \mathrm{a}$ \\
\hline $\mathrm{I}_{100}$ & $62.02 \mathrm{a}$ & $59.16 \mathrm{ab}$ & $\mathrm{I}_{100}$ & $46.79 \mathrm{a}$ & $46.57 \mathrm{a}$ \\
\hline
\end{tabular}




\begin{tabular}{|c|c|c|c|c|c|}
\hline \multicolumn{3}{|c|}{2018 yr } & \multicolumn{3}{|c|}{$2018 \mathrm{yr}$} \\
\hline $\mathrm{I}_{25}$ & $52.90 \mathrm{c}$ & $51.73 \mathrm{c}$ & $\mathrm{I}_{25}$ & $44.12 \mathrm{c}$ & $42.50 \mathrm{~d}$ \\
\hline $\mathrm{I}_{50}$ & $56.14 \mathrm{bc}$ & $55.10 \mathrm{bc}$ & $\mathrm{I}_{50}$ & $44.69 \mathrm{c}$ & $44.20 \mathrm{c}$ \\
\hline $\mathrm{I}_{75}$ & $59.99 \mathrm{~b}$ & $57.91 \mathrm{~b}$ & $\mathrm{I}_{75}$ & $46.01 \mathrm{~b}$ & $46.07 \mathrm{~b}$ \\
\hline $\mathrm{I}_{100}$ & $66.40 \mathrm{a}$ & $58.72 \mathrm{~b}$ & $\mathrm{I}_{100}$ & $48.06 \mathrm{a}$ & $46.76 \mathrm{~b}$ \\
\hline \multicolumn{3}{|c|}{ TSS/TA ratio } & \multicolumn{3}{|c|}{ Colour a } \\
\hline Irrigation & Mulch & No mulch & Irrigation & Mulch & No mulch \\
\hline \multicolumn{3}{|c|}{$2017 \mathrm{yr}$} & \multicolumn{3}{|c|}{ Average of two years } \\
\hline $\mathrm{I}_{25}$ & $19.87 \mathrm{~b}$ & $19.67 \mathrm{~b}$ & $\mathrm{I}_{25}$ & $34.45 \mathrm{~b}$ & $36.58 \mathrm{a}$ \\
\hline $\mathrm{I}_{50}$ & $21.17 \mathrm{ab}$ & $21.20 \mathrm{ab}$ & $\mathrm{I}_{50}$ & $33.20 \mathrm{c}$ & $3216 \mathrm{c}$ \\
\hline $\mathrm{I}_{75}$ & $2262 \mathrm{a}$ & $22.61 \mathrm{a}$ & $\mathrm{I}_{75}$ & $33.15 \mathrm{c}$ & $35.02 \mathrm{~b}$ \\
\hline $\mathrm{I}_{100}$ & $23.12 \mathrm{a}$ & $21.36 \mathrm{ab}$ & $\mathrm{I}_{100}$ & $32.89 \mathrm{c}$ & $37.39 \mathrm{a}$ \\
\hline \multicolumn{3}{|c|}{$2018 \mathrm{yr}$} & \multicolumn{3}{|c|}{ Average colour b } \\
\hline $\mathrm{I}_{25}$ & $23.19 \mathrm{bc}$ & $25.54 \mathrm{ab}$ & $\mathrm{I}_{25}$ & $29.58 \mathrm{a}$ & $30.36 \mathrm{a}$ \\
\hline $\mathrm{I}_{50}$ & $21.98 \mathrm{c}$ & $24.89 \mathrm{abc}$ & $\mathrm{I}_{50}$ & $29.37 \mathrm{ab}$ & $29.61 \mathrm{a}$ \\
\hline $\mathrm{I}_{75}$ & $26.22 \mathrm{ab}$ & $26.84 \mathrm{a}$ & $\mathrm{I}_{75}$ & $29.76 \mathrm{a}$ & $27.29 c$ \\
\hline $\mathrm{I}_{100}$ & $25.52 \mathrm{abc}$ & $23.22 \mathrm{bc}$ & $\mathrm{I}_{100}$ & $28.24 \mathrm{bc}$ & $27.80 \mathrm{c}$ \\
\hline
\end{tabular}

\section{Conclusions}

According to the results of this research, irrigation water level, mulch application and irrigation water-mulch interaction had significant effects on the quality of tomato. The study shows that $\mathrm{pH}$, fruit puncture resistance, fruit diameter, fruit length and TSS/TA ratio increased with increasing amount of irrigation water. Mulch application was found to increase these quality criteria regardless of irrigation water levels. The best results were obtained from fully irrigated $\left(\mathrm{I}_{100}\right)$ subjects in both years. In some quality parameters, there was no significant difference between $\mathrm{I}_{75}$ and $\mathrm{I}_{100}$ applications. As a result, it can clearly be stated that as the irrigation level increased, the quality criteria characteristics examined within this study gave better results.

Acknowledgements. This paper is extracted from the $\mathrm{PhD}$ dissertation of the first author from the Biosystems Engineering Department of Agriculture and Natural Sciences Faculty of Bilecik Şeyh Edebali University. Authors are also grateful to Bilecik Seyh Edebali University Scientific Research Projects Department for supporting the experiment through Project no: 2018-01. BSEÜ.06-01 at Bilecik location.

\section{REFERENCES}

[1] Abak K., Pakyürek A. Y., Gürsöz N., Onsinejad R. (1990): Effect of mulch applications on soil temperature in greenhouse, yield and earliness of some vegetables. - Turkey V. Greenhouse Symposium, 17-19 October, İzmir, 55-62.

[2] Ahmadi, S. H., Andersen, M. N., Plauborg, F., Poulsen, R. T., Jensen, C. R., Sepaskhah, A. R., Hansen, S. (2010): Effects of irrigation strategies and soils on field grown potatoes: yield and water productivity. - Agricultural Water Management 97(11): 19231930. 
[3] Allen, R. G., Pereira, L. S., Raes, D., Smith, M. (1998): Crop evapotranspiration. guidelines for computing crop water requirements. - FAO Irrigation Drainage Paper No. 56 , FAO, Rome, Italy.

[4] Anonymous (2014): Water and water management in Turkey condition new approach: environmental perspectives. - Nature Conservation Center. www.tbcsd.org, www.dkm.org.tr.

[5] Biswas, S. K., Akanda, A. R., Rahman, M. S., Hossain, M. A. (2015): Effect of drip irrigation and mulching on yield, water-use efficiency and economics of tomato. - Plant, Soil and Environment 61(3): 97-102.

[6] Cemeroğlu, B. (2010): Food Analyzes. Expanded $2^{\text {nd }}$ Ed. - Food Technology Association Publications, No: 34, Ankara.

[7] Ekinci, M., Dursun, A. (2009): Effects of different mulch materials on plant growth, some quality parameters and yield in melon (Cucumis melo L.) cultivars in high altitude environmental condition. - Pakistan Journal of Botany 41(4): 1891-1901.

[8] Ertek, A., Erdal I., Yilmaz H. I., Senyigit U. (2012): Water and nitrogen application levels for the optimum tomato yield and water use efficiency. - J. Agric. Sci. Technol. 14: 889-902.

[9] FAO (2011): The State of the World's Land and Water Resources for Food and Agriculture: Managing Systems at Risk. - Land and Water Division, FAO/Earthscan, Rome/London.

[10] FAO (2013): Aquastat 2013. - http://www.fao.org/nr/water/aquastat/main/index.stm.

[11] FAO (2018): FAOSTAT. - http://www.fao.org/faostat/en/\#home.

[12] Favati, F., Lovelli, S., Galgano, F., Miccolis, V., Di Tommaso, T., Candido, V. (2009): Processing tomato quality as affected by irrigation scheduling. - Scientia Horticulturae 122(4): 562-571.

[13] Garrity, D. P., Watts, D. G., Sullivan, C. Y., Gilley, J. R. (1982): Moisture deficits and grain sorghum performance: evapotranspiration-yield relationships 1. - Agronomy Journal 74(5): 815-820.

[14] Hanson, B. R., May, D. M. (2006): Crop evapotranspiration of processing tomato in the San Joaquin Valley of California, USA. - Irrigation Science 24(4): 211-221.

[15] Hatami, S., Nourjou, A., Henareh, M., Pourakbar, L. (2012): Comparison effects of different methods of black plastic mulching and planting patterns on weed control, wateruse efficiency and yield in tomato crops. - International Journal of Agri Science 2(10): 928-934.

[16] Kanber, R. (1984): Irrigation of first and second product peanuts by utilizing open water surface evaporation in Çukurova conditions. - Regional Groundwater Research Institute Publications 114: 64-93.

[17] Koçar, G. (2001): Effects of mulching with different colored polyethylene on lettuce production on greenhouse. - Journal of Aegean Agricultural Research Institute 11(1): 47 55 .

[18] Korkmaz S. S., Balkaya, A. (2016): The effects of different coloured mulch application on earliness, yield and quality in snap bean (Phaselous vulgaris L.) cultivation during autumn season. - Journal of Atatürk Central Horticultural Research Institute 45(2): 278282.

[19] Kurtar, E. S. (2010): The effects of mulch applications on summer squash (Cucurbita pepo L.) production in an unheated glasshouse in autumn season. - Harran Journal of Agricultural and Food Science 14(2): 69-76.

[20] Kuşçu, H., Turhan, A., Demir, A. O. (2014): The response of processing tomato to deficit irrigation at various phenological stages in a sub-humid environment. - Agricultural Water Management 133: 92-103.

[21] Lahoz, I., Pérez-de-Castro, A., Valcárcel, M., Macua, J. I., Beltrán, J., Roselló, S., Cebolla-Cornejo, J. (2016): Effect of water deficit on the agronomical performance and quality of processing tomato. - Scientia Horticulturae: 200: 55-65. 
[22] Lascano, R. J., Sojka, R. E. (2007): Irrigation of Agricultural Crops. $2^{\text {nd }}$ Ed. - ASA Agronomy Monograph, 30. American Society of Agronomy, Madison.

[23] Locascio, S. J., Smajstrla, A. G. (1996): Water application scheduling by pan evaporation for drip-irrigated tomato. - Journal of the American Society for Horticultural Science 121(1): 63-68.

[24] Mukherjee, A., Kundu, M., Sarkar, S. (2010): Role of irrigation and mulch on yield, evapotranspiration rate and water use pattern of tomato (Lycopersicon esculentum L.). Agricultural Water Management 98(1): 182-189.

[25] Patanè, C., Cosentino, S. L. (2010): Effects of soil water deficit on yield and quality of processing tomato under a Mediterranean climate. - Agricultural Water Management 97(1): 131-138.

[26] Salokhe, V. M., Babel, M. S., Tantau, H. J. (2005): Water requirement of drip irrigated tomatoes grown in greenhouse in tropical environment. - Agricultural Water Management 71(3): 225-242.

[27] Samaila, A. A., Amans, E. B., Babaji, B. A. (2011): Yield and fruit quality of tomato (Lycopersicon esculentum Mill) as influenced by mulching, nitrogen and irrigation interval. - International Research Journal of Agricultural Science and Soil Science 1(3): 90-95.

[28] Tar1, A. F., Sapmaz, M. (2017): The effect of different irrigation levels on the yield and quality. - Soil Water Journal 6(2): 11-17.

[29] Ünlü, H. Ö., Ünlü, H., Karataş, A., Padem, H., Kitiş, Y. E. (2006): The effect of different mulch color on the yield and quality properties of tomato. - Alatarım 5(1): 10-14.

[30] Wang, Q., Li, F., Zhang, E., Li, G., Vance, M. (2012): The effects of irrigation and nitrogen application rates on yield of spring wheat (longfu-920), and water use efficiency and nitrate nitrogen accumulation in soil. - Australian Journal of Crop Science 6(4): 662672.

[31] Zegbe-Dominguez, J. A., Behboudian, M. H., Lang, A., Clothier, B. E. (2003): Deficit irrigation and partial rootzone drying maintain fruit dry mass and enhance fruit quality in 'Petopride' processing tomato (Lycopersicon esculentum, Mill.). - Scientia Horticulturae 98(4): 505-510.

[32] Zoran, I. S., Nikolaos, K., Ljubomir, Š. (2014): Tomato Fruit Quality from Organic and Conventional Production. - In: Pilipavicius, V. (ed.) Organic Agriculture Towards Sustainability. InTech Europe, Rijeka, Croatia, pp: 147-169. 